\title{
Stress Distribution in an Elastic Rod Subjected to Initial Tip Displacement
}

\author{
Mehmet N. Balci ${ }^{1 *}$

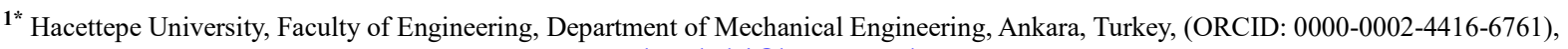 \\ mehmetbalci@hacettepe.edu.tr
}

(1st International Conference on Applied Engineering and Natural Sciences ICAENS 2021, November 1-3, 2021)

(DOI: 10.31590/ejosat.1015624)

ATIF/REFERENCE: Balci, M.N. (2021). Stress Distribution in an Elastic Rod Subjected to Initial Tip Displacement. European Journal of Science and Technology, (28), 1348-1355.

\begin{abstract}
This study presents computational method to examine the displacement and stress distribution within an elastic rod made of different materials. Steel, aluminum alloys and titanium alloys have been widely used in many engineering fields such as automotive, aerospace, energy and medical applications. Hence, dynamic displacement and stress distributions in elastic rods manufactured by these materials has a crucial importance. In order to obtain displacement and stress, wave propagation problem is modeled based on one dimensional (1-D) wave equation. Boundary conditions are assumed as fixed-free, and elastic rod is subjected to tip displacement at free end, initially. Analytical solution is performed by means of separation of variables, and natural frequencies and displacement distributions are found. Computational method is developed based on the discretization of wave equation in space and time parameters utilizing explicit scheme. Displacement and stress distribution within the elastic rod is obtained computationally. Analytically and computationally obtained results are compared, and excellent agreement is achieved. Then, parametric analyses are conducted to examine the influences of time, the level of tip load and material type on displacement and stress distributions. It is observed that developed computational method is fast and reliable in accurate determination of displacement and stress within elastic rod made of various kinds of materials.
\end{abstract}

Keywords: Longitudinal wave, Elastic rod, Analytical method, Explicit method, Stress distribution.

\section{İlk Uç Yer değiştirmesine Maruz Kalan Elastik Çubukta Gerilme Dağılımı}

$\ddot{\mathrm{O} z}$

$\mathrm{Bu}$ çalışma, farklı malzemelerden yapılmış bir elastik çubuk içerisindeki yer-değiştirme ve gerilme dağılımlarını incelemek için hesaplamalı bir yöntem sunmaktadır. Çelik, alüminyum alaşımları ve titanyum alaşımları otomotiv, havacılık, enerji ve tıbbi uygulamalar gibi birçok mühendislik alanında yaygın olarak kullanılmaktadır. Bu nedenle, bu malzemelerden imal edilen elastik çubuklarda dinamik yer-değiştirme ve gerilme dağılımları büyük önem taşımaktadır. Yer-değiştirme ve gerilmeyi elde etmek için dalga yayılım problemi tek boyutlu (1-D) dalga denklemi esas alınarak modellenmiştir. Sınır koşulları sabit-serbest olarak kabul edilmiştir ve elastik çubuk başlangıçta serbest uçta uç yer-değiştirmesine maruz bırakılmıştır. Analitik çözüm, değişkenlerin ayrılması yoluyla gerçekleştirilir ve doğal frekanslar ve yer-değiştirme dağılımları bulunur. Hesaplamalı yöntem açık (explicit) şema kullanılarak uzay ve zaman parametrelerinde dalga denkleminin ayrıklaştırılmasına dayalı olarak geliştirilmiştir. Elastik çubuk içindeki yer-değiştirme ve gerilme dağılımı hesaplamalı olarak elde edilir. Analitik ve hesaplamalı olarak elde edilen sonuçlar karşıllaştırılır ve mükemmel bir uyum sağlanır. Daha sonra, zaman, uç yük seviyesi ve malzeme tipinin yer-değiştirme ve gerilme dağılımlarına olan etkisini incelemek için parametrik analizler yapılır. Geliştirilen hesaplamalı yöntemin farklı tür malzemelerden imal edilmiş elastik çubukta yer-değiştirme ve gerilme dağılımlarının doğru şekilde belirlenmesinde hızlı ve güvenilir olduğu gözlemlenmiştir.

Anahtar Kelimeler: Boyuna dalga, Elastik çubuk, Analitik yöntem, Açık yöntem, Gerilme dağılımı.

\footnotetext{
* Corresponding Author: mehmetbalci@hacettepe.edu.tr
} 


\section{Introduction}

Bars and rods are widely used in industry as machine components such as wire rods, connecting rods, crankshafts, turbine shafts. Therefore, dynamic stress response of these components are significant in design process. Steels AISI 1006, AISI 1020 steels are used in panels in automobiles, camshafts, pins, axles and light duty gears. Ti6Al4V is lightweight and strong material which is very suitable in the utilization of jet engines, gas turbines and many airframe components. (Inagaki et al., 2014; Boyer, 1996; Singh et al., 2017; Uhlmann et al., 2015). However, marine, automotive, energy and medical industries have interested this alloy during the last century. Al alloy 6061 is used in automotive steering knuckles (Jeon et al., 2018) since it was reported that it reduced the vehicle weight (Sharma et al., 2011; Vijayarangan et al., 2013). The behavior of the stress waves within the material is important in the aspect of dynamic material response. Elastic waves and vibrations of thin rods were examined (Prescott, 1942). The propagation of longitudinal waves along cylindrical bars was studied analytically by Kolsky (1954). Hutchinson (1972) and Hutchinson (1980) investigated vibrations of finite length rod and solid cylinder. A series solution was developed for the longitudinal vibration of elastically restrained rods (Xu et al., 2019). Yang et al. (2021) conducted an analytical work based on Laplace transformation to find propagation of stress pulses in a Rayleigh-Love elastic rod. Solution of wave problems using analytical methods is generally laborious and time-consuming.

This study shows the efficiency of the computational method based on explicit scheme for longitudinal wave propagation problems in elastic rods. Dynamic stress distribution is calculated through the use of higher order finite difference formula, and obtained displacement and stress results display a high degree of accuracy with analytically or theoretically obtained results. Parametric studies are conducted to observe the effect of time, tip displacement and material type on displacement and dynamic stress behavior.

\section{Problem Model and Formulation}

The general schematic of the addressed problem is depicted by Fig. 1. Elastic rod with a constant circular cross-section has a length $L$ and subjected to initial tip displacement $u_{0}$ at the right end. $x$ axis indicates the longitudinal direction. The left end is clamped, hence elastic rod is under fixed-free boundary conditions. The right end of the bar is always stress-free while interior sections expose to stress sue to wave propagation. $E$ and $\rho$ respectively show the elastic modulus and the mass density of the material.

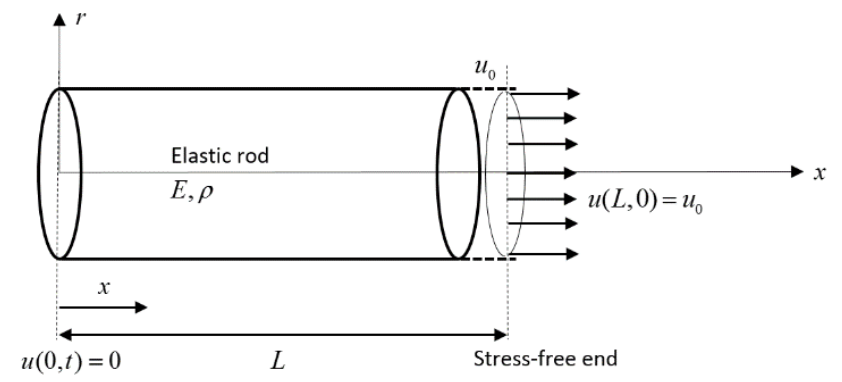

Fig. 1 Elastic rod subjected to initial tip displacement.
The longitudinal propagation of the wave within the elastic rod is modelled based on the one-dimensional (1D) wave propagation equation. This equation involves space and time variables as:

$$
\begin{aligned}
& \rho \frac{\partial^{2} u(x, t)}{\partial t^{2}}=E \frac{\partial^{2} u(x, t)}{\partial x^{2}}, 0 \leq x \leq L, t \geq 0, \\
& u(0, t)=0, \quad \frac{\partial u(L, t)}{\partial x}=0, \quad t \geq 0, \\
& u(x, 0)=f(x)=u_{0} \frac{x}{L}, \quad 0 \leq x \leq L . \\
& u_{t}(x, 0)=g(x), \quad 0 \leq x \leq L .
\end{aligned}
$$

The analytical solution of this 1D partial differential equation is performed by using separation of variables technique as follows:

$$
\frac{T^{\prime \prime}}{c^{2} T}=\frac{X^{\prime \prime}}{X}=-\lambda^{2},
$$

where $c=\sqrt{\frac{E}{\rho}}$.

$$
\begin{aligned}
& X(x)=C_{1} \sin (\lambda x)+C_{2} \cos (\lambda x), \\
& T(t)=C_{1} \sin (\lambda c t)+C_{2} \cos (\lambda c t),
\end{aligned}
$$

When solutions given by Eq. (6) and Eq. (7) is combined, following general solution is obtained.

$$
\begin{aligned}
u(x, t) & =D_{1} \sin (\lambda x) \cos (\lambda c t) \\
+ & D_{2} \sin (\lambda x) \sin (\lambda c t) \\
+ & D_{3} \cos (\lambda x) \cos (\lambda c t) \\
+ & D_{4} \sin (\lambda x) \sin (\lambda c t) .
\end{aligned}
$$

$D_{1}, D_{2}, D_{3}$ and $D_{4}$ are unknown constants to be determined from boundary and initial conditions. Since $u(0, t)=0, D_{3}$ and $D_{4}$ are zero. Hence, solution becomes as:

$$
\begin{gathered}
u(x, t)=D_{1} \sin (\lambda x) \cos (\lambda c t) \\
+D_{2} \sin (\lambda x) \sin (\lambda c t) .
\end{gathered}
$$

When stress-free end boundary condition is applied $u_{x}(L, t)=0$, the following equation is obtained.

$$
\lambda_{n}=\frac{(2 n-1) \pi}{2 L}, \quad n=\mp 1,2,3, \ldots
$$

The natural frequencies of the bar is calculated using following formula:

$$
\begin{aligned}
& \omega_{n}=\frac{c(2 n-1) \pi}{2 L}, n=\mp 1,2,3, \ldots \\
& D_{1 n}=\frac{2}{L} \int_{0}^{L} u_{0} \frac{x}{L} \sin \left(\frac{n \pi x}{2 L}\right) d x, \\
& D_{1 n}=2 u_{0}\left(\frac{4}{n^{2} \pi^{2}} \sin \left(\frac{n \pi}{2}\right)-\frac{2}{n \pi} \cos \left(\frac{n \pi}{2}\right)\right),
\end{aligned}
$$




$$
D_{2 n}=0 \text {, }
$$

Unknown coefficients are determined and general solution is obtained as:

$$
u(x, t)=\sum_{n=1}^{N} D_{1 n} \sin \left(\lambda_{n} x\right) \cos \left(\lambda_{n} c t\right) .
$$

The computational method is developed based on the explicit scheme. The governing partial differential equation given by Eq. (1) is discretised in space and time.

$$
\frac{u_{i}^{j+1}-2 u_{i}^{j}+u_{i}^{j+1}}{(\Delta t)^{2}}=c^{2} \frac{u_{i}^{j+1}-2 u_{i}^{j}+u_{i-1}{ }^{j}}{(\Delta x)^{2}},
$$

Eq. (16) can be written in a more compact form by introducing the Courant number as $\alpha=c \Delta t / \Delta x$ (Cangellaris, 1993).

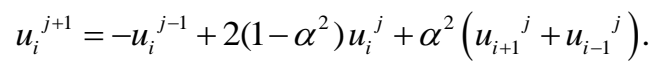

The proper solution can only be generated with convenient selection of space and time parameters which should satisfy the von Neumann stability analysis such as:

$$
\alpha=\frac{c \Delta t}{\Delta x} \leq 1
$$

If condition provided by Eq. (18) is not satisfied, no proper solution can be generated. Boundary condition at fixed-end requires:

$$
u_{0}^{j}=0
$$

Boundary condition at stress-free end is applied using central difference as follows:

$$
u_{N+1}^{j}=2 C \Delta x+u_{N-1}^{j} .
$$

where $C=0$ due to the since stress-free condition. At each time step, following equation should be calculated due to the specified boundary conditions. Space steps and time steps used in explicit scheme are displayed in Fig. 2. $\Delta x$ and $\Delta t$ show the space and time steps, respectively. Calculation of displacement $u_{i}{ }^{1}$ is marked with box with red line.

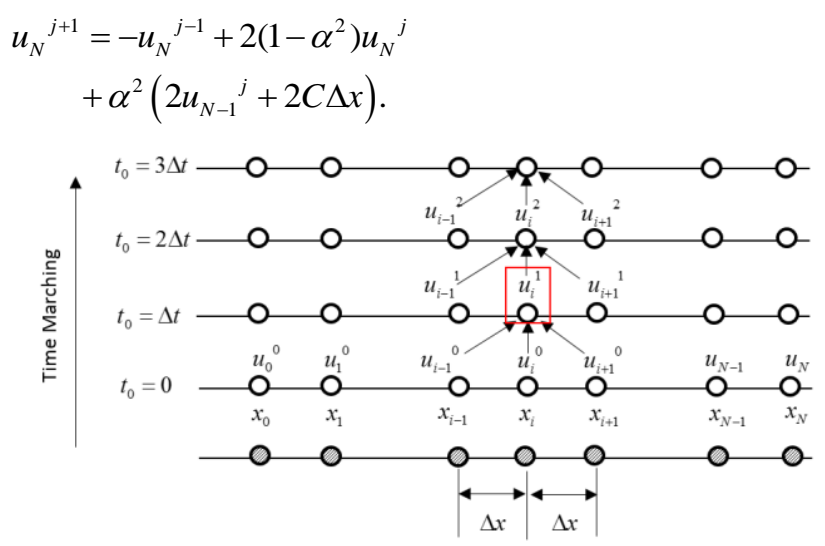

Fig. 2 Schematics of the explicit scheme for space and time variables.
Initial conditions are applied and following starter equation is obtained.

$$
u_{i}{ }^{1}=\Delta t g_{i}+\left(1-\alpha^{2}\right) u_{i}^{0}+\frac{1}{2} \alpha^{2}\left(u_{i+1}{ }^{0}+u_{i-1}{ }^{0}\right) .
$$

Since no velocity is defined within the rod initially, $g_{i}=0$.

Stress within the elastic rod is calculated using Hooke's law as follows:

$$
\sigma=E \varepsilon_{x}
$$

where $\varepsilon_{x}=\partial u / \partial x$. Initial theoretical stress in the elastic rod subjected to tip displacement $u_{0}$ can be calculated using:

$$
\sigma_{\text {theoretical }}=\frac{u_{0} E}{L}
$$

The term $\partial u / \partial x$ is calculated using higher order forward, centred and backward finite difference formulations, and computational stresses are expressed as:

$$
\begin{aligned}
\sigma_{0}{ }^{j} & =E \frac{\partial u_{0}^{j}}{\partial x} \\
& =E\left(\frac{-u_{2}^{j}+4 u_{1}^{j}-3 u_{0}^{j}}{2 \Delta x}\right),
\end{aligned}
$$

$$
\begin{aligned}
\sigma_{i}^{j} & =E \frac{\partial u_{i}^{j}}{\partial x} \\
& =E\left(\frac{\left.-u_{i+2}^{j}+8{u_{i+1}^{j}-8 u_{i-1}^{j}+u_{i-2}^{j}}_{12 \Delta x}^{j}\right)}{}\right.
\end{aligned}
$$

$$
\begin{aligned}
\sigma_{N}{ }^{j} & =E \frac{\partial u_{N}{ }^{j}}{\partial x} \\
& =E\left(\frac{3 u_{N}{ }^{j}-4 u_{N-1}{ }^{j}+u_{N-2}{ }^{j}}{2 \Delta x}\right) .
\end{aligned}
$$

\section{Results and Discussion}

In this section, results are generated to examine the influence of time, level of tip deflection and material type on displacement and stress distributions. AISI 1006 (CD), AISI 1020 (CD), Ti6Al4V and Al alloy 6061 were utilized in longitudinal wave propagation analysis. Table 1 shows material properties (elastic modulus and mass density) for these materials with constituent elements as well (Matweb, 2021). It is observed that the elastic modulus for AISI 1006 (CD) is the highest while elastic modulus of the $\mathrm{Al}$ alloy 6061 is the lowest. Elastic modulus for the AISI 1020 (CD) steel is less than that of AISI 1006 (CD) steel since Carbon composition is increased $0.17-0.23 \%$ for this material.

Table 2 indicates wave propagation speeds for different materials utilized in wave propagation and stress analysis in the elastic rod.

Fig. 3 illustrates the mode shapes of the fixed-free elastic rod. While generating mode shapes, Eq. (6) is used. Maximum deflection is seen at Mode 1 at the free end of the rod. As Mode number is increased to $2,3,4,5, \ldots$, etc. deflection tend to decrease within the rod. The natural frequencies are generated for Ti6Al4V rod based on Eq. (11), and these frequencies are 
provided in Table 3. Natural frequencies are increasing for higher mode numbers. First natural frequencies for AISI 1006 (CD), AISI 1020 (CD), Al alloy 6061 are 8035.4 Hz, 7636.4 Hz, 7940 $\mathrm{Hz}$, respectively. The lowest natural frequency is observed for AISI 1020 (CD) steel.

Table 1. Material properties.

\begin{tabular}{|c|c|c|c|}
\hline Material & $\begin{array}{c}\text { Elastic } \\
\text { Modulus } \\
(\text { GPa) }\end{array}$ & $\begin{array}{l}\text { Density } \\
{\left[\mathrm{kg} / \mathrm{m}^{3}\right]}\end{array}$ & Constituents \\
\hline $\begin{array}{l}\text { AISI } 1006 \\
\quad(C D)\end{array}$ & 206 & 7872 & $\begin{array}{l}=0.08 \% \mathrm{C} \\
99.43-99.75 \% \mathrm{Fe} \\
0.25-0.40 \% \mathrm{Mn} \\
<=0.040 \% \mathrm{P} \\
<=0.050 \% \mathrm{~S}\end{array}$ \\
\hline $\begin{array}{l}\text { AISI } 1020 \\
\quad(C D)\end{array}$ & 186 & 7870 & $\begin{array}{l}0.17-0.23 \% \mathrm{C} \\
99.08-99.53 \% \mathrm{Fe} \\
0.30-0.60 \% \mathrm{Mn} \\
<=0.040 \% \mathrm{P} \\
<=0.050 \% \mathrm{~S}\end{array}$ \\
\hline Ti6Al4V & 113.8 & 4430 & $\begin{array}{l}<=0.08 \% \mathrm{C} \\
<=0.015 \% \mathrm{H} \\
<=0.040 \% \mathrm{Fe} \\
<=0.030 \% \mathrm{~N} \\
87.725-91 \% \mathrm{Ti} \\
3.5-4.5 \% \mathrm{~V} \\
\text { Others }<=0.30 \%\end{array}$ \\
\hline $\begin{array}{c}\text { Al alloy } \\
6061\end{array}$ & 69.0 & 2700 & $\begin{array}{l}96.15-98.61 \% \mathrm{Al} \\
0.040-0.35 \% \mathrm{Cr} \\
0.15-0.40 \% \mathrm{Cu} \\
<=0.70 \% \mathrm{Fe} \\
0.80-1.2 \% \mathrm{Mg}\end{array}$ \\
\hline
\end{tabular}

Table 2. Longitudinal wave propagation speeds for various materials.

\begin{tabular}{|c|c|}
\hline Material & Wave speed c $[\mathbf{m} / \mathbf{s}]$ \\
\hline AISI 1006 $(\mathrm{CD})$ & 5115.5 \\
\hline AISI 1020 $(\mathrm{CD})$ & 4861.5 \\
\hline Ti6Al4V & 5068.4 \\
\hline Al alloy 6061 & 5055.3 \\
\hline
\end{tabular}

Table 3. Natural frequencies for Ti6Al4V elastic rod.

\begin{tabular}{|c|c|}
\hline Mode no & Frequency [Hz] \\
\hline 1 & 7961.39 \\
\hline 2 & 23884.18 \\
\hline 3 & 39806.97 \\
\hline 4 & 55729.76 \\
\hline 5 & 71652.55 \\
\hline
\end{tabular}

Longitudinal wave propagates from the free end towards the fixed end of rod. The length of the rod is assumed as $L=1 \mathrm{~m}$. This wave reaches the fixed end at specified time named as reflection time $t_{r}$. When longitudinal wave hits the fixed end, it reflects from this fixed end and propagates back to the free-end. The reflection time can simply be found by,

$$
t_{r}=\frac{L}{c}
$$

Fig. 4 depicts the displacement distribution in the elastic rod made of Ti6Al4V for various times corresponds to before reflection $\left(t_{r} / 2\right)$, reflection $\left(t_{r}\right)$ and after reflection $\left(3 t_{r} / 2\right)$.

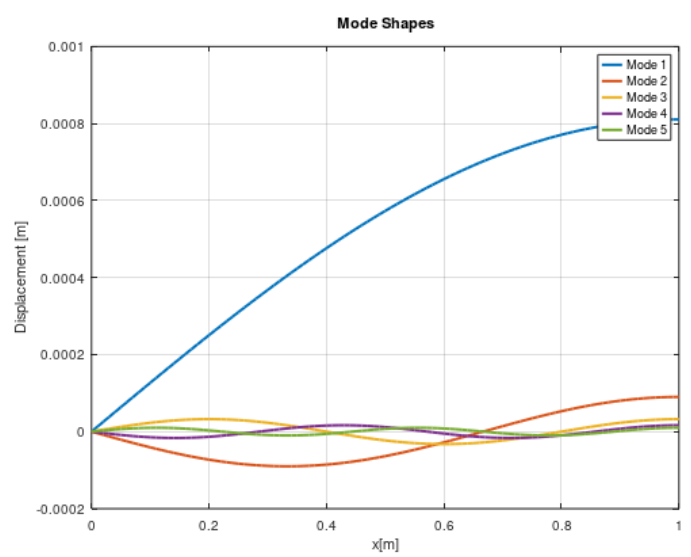

Fig. 3 Mode shapes of the elastic rod.

a)

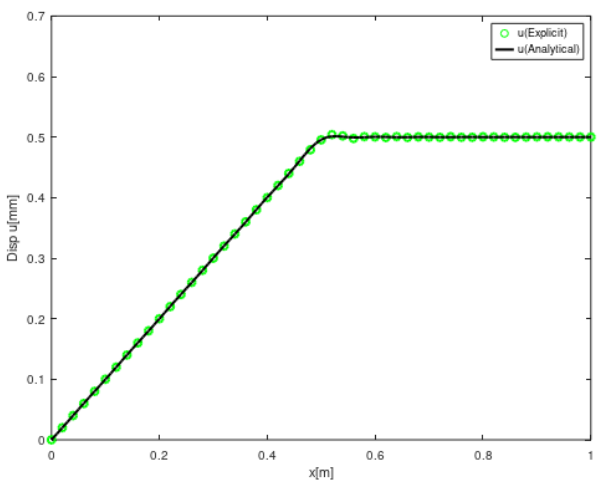

b)

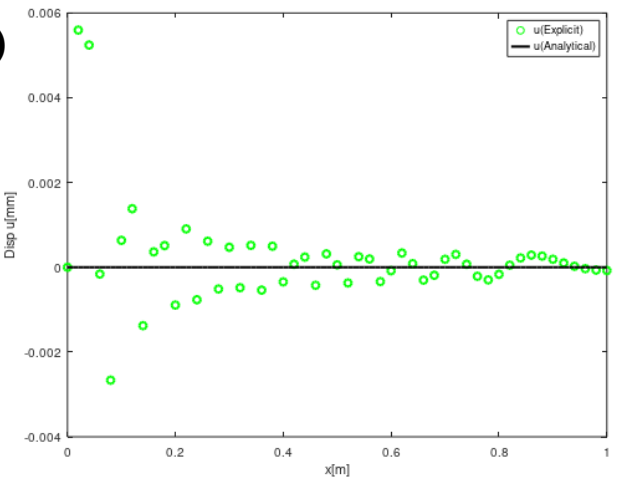

c)

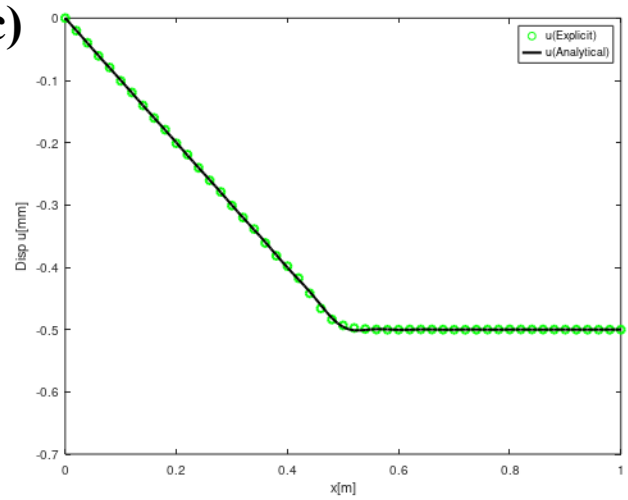

Fig. 4 Displacement distribution in Ti6Al4V rod for various time, $u_{0}=1 \mathrm{~mm}$, (a) $t=t_{r} / 2$, (b) $t=t_{r}$, (c) $t=3 t_{r} / 2$. 
Black solid line shows the displacement distribution obtained by analytical solution while green dot points indicate displacement distribution acquired by computational method. It can obviously seen that results obtained by two different methods exhibit high level of accuracy, that implies the power of computational method on wave propagation analysis. Fig. 4(a) and Fig. 4(c) shows displacements before reflection and after reflection, respectively. Slight amount of difference occur between analytical and computational results only in reflection time $\left(t_{r}\right)$ as seen in Fig. 4(b) due to the participation of rounding errors at that time.

Fig. 5(a) illustrates the displacement distribution within the Ti6Al4V rod for various levels of the initial tip displacement. Time is set to $t=t_{r} / 2$ which shows the wave propagation before the reflection. Displacement level becomes the half of the applied initial tip displacement in the middle of the $\operatorname{rod}(L / 2)$. It can be inferred from Fig. 5(a) that computational result display a high degree of accuracy with analytical result for various levels of initial tip displacement. Fig. 5(b) demonstrates the dynamic stress distribution obtained computationally in Ti6Al4V rod by red dot points at time $t=t_{r} / 2$ (before reflection). The black solid line in Fig. 5(b) indicates theoretical initial stress within the Ti6Al4V rod according to the formula given in Eq. (24). Hence these stresses are $113.8 \mathrm{MPa}, 227.8 \mathrm{MPa}$ and $569 \mathrm{MPa}$ for tip displacements $u_{0}=1 \mathrm{~mm}, u_{0}=2 \mathrm{~mm}$ and $u_{0}=5 \mathrm{~mm}$, respectively. Longitudinal wave propagation starts from free-end at $t=0$ and when time become $t=t_{r} / 2$, this wave stands in the middle of the rod $(L / 2)$. Therefore, dynamic stress tend to zero $(\sigma=0)$ after $x=0.5 \mathrm{~m}$. Between the interval of $0 \leq x \leq 0.5 \mathrm{~m}$, stresses are not zero and again theoretically obtained initial stress and computationally acquired dynamic stress display a high level of accuracy. Fig. 6 Fig. 9 show stress distribution in AISI 1006 (CD), AISI 1020
(CD), Ti6Al4V, Al alloy 6061 rod, respectively. Black solid line shows the theoretical stress initially and blue dot points show dynamic stresses at initial time $u_{i}^{0}$. In these figures, red dotted lines demonstrate dynamic stress distribution obtained by developed computational method.

\section{a)}

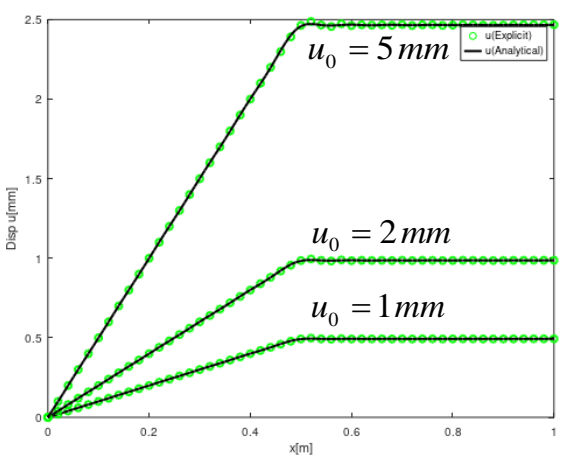

b)

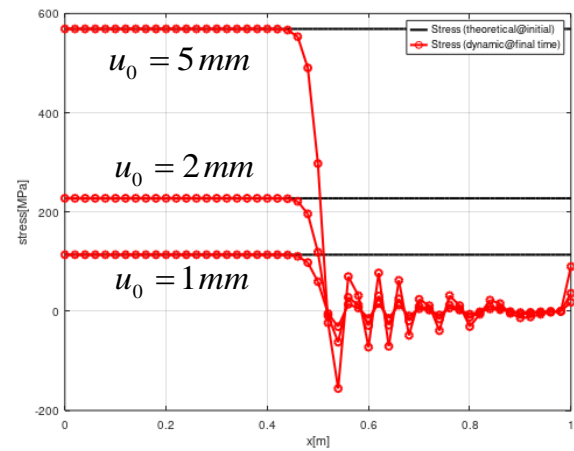

Fig. 5 (a) Displacement, (b) Stress distribution in Ti6Al4V rod for various values of tip displacements, $u_{0}=1 \mathrm{~mm}, u_{0}=2 \mathrm{~mm}$, $u_{0}=5 \mathrm{~mm}$. a)

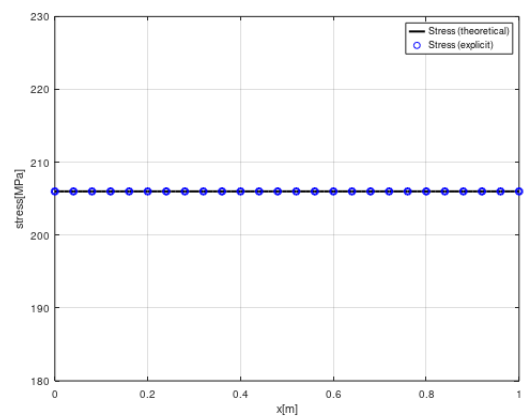

c)

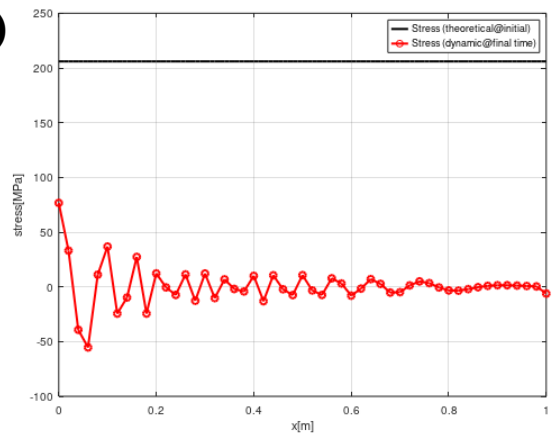

b)

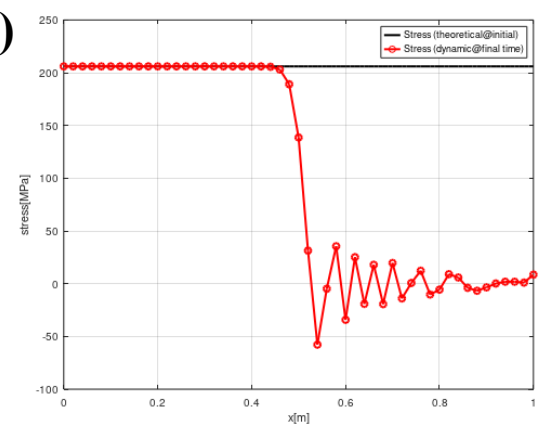

d)

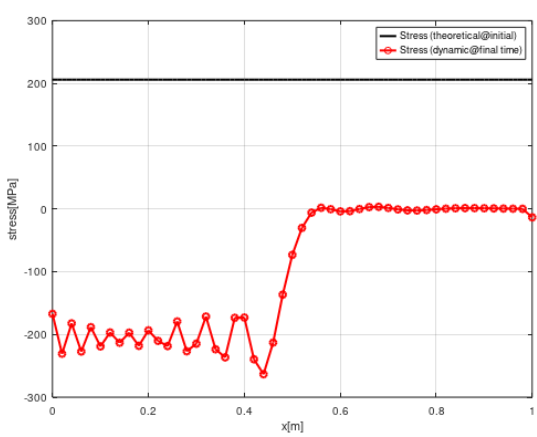

Fig. 6 Dynamic stress distribution in AISI 1006 (CD) steel rod for various values time $u_{0}=1 \mathrm{~mm}$, (a) $t=0 s$, (b) $t=t_{r} / 2$, (c) $t=t_{r}$, (d) $t=3 / 2 t_{r}$. 
a)

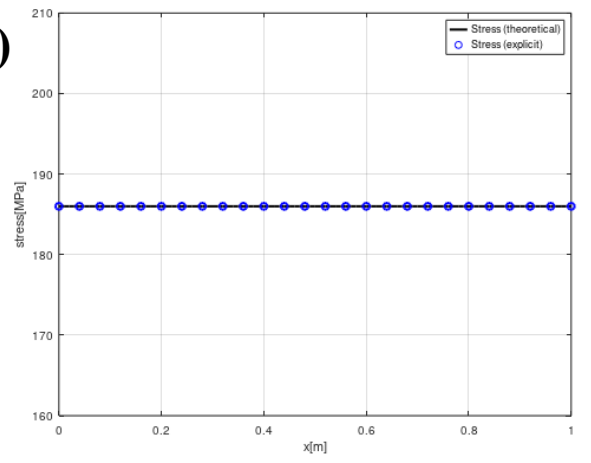

c)

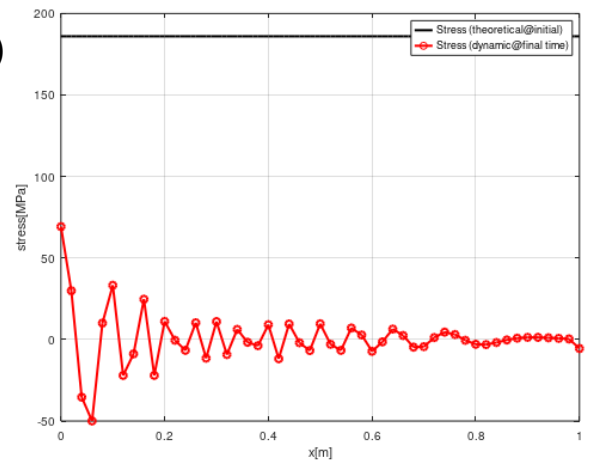

b)

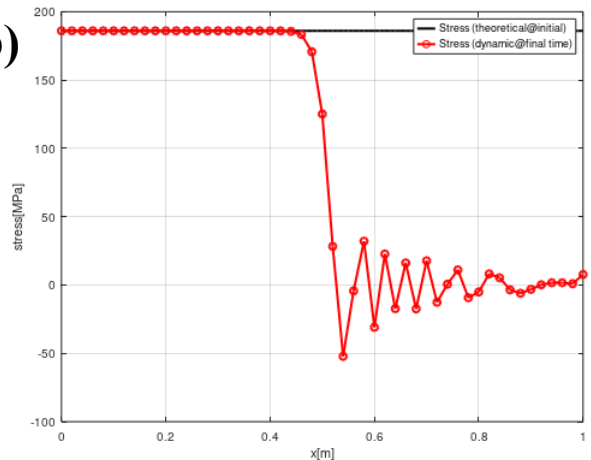

d)

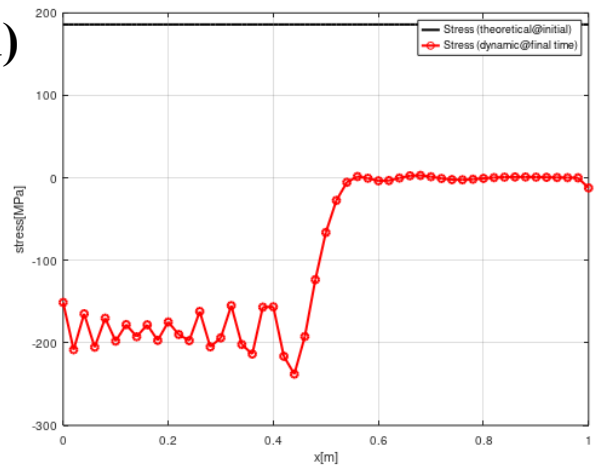

Fig. 7 Dynamic stress distribution in AISI 1020 (CD) steel rod for various values time $u_{0}=1 \mathrm{~mm}$, (a) $t=0 \mathrm{~s}$, (b) $t=t_{r} / 2$, (c) $t=t_{r}$, (d) $t=3 / 2 t_{r}$.

a)

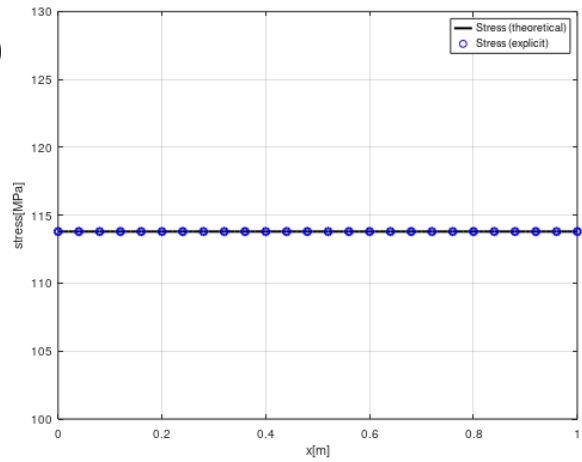

c)

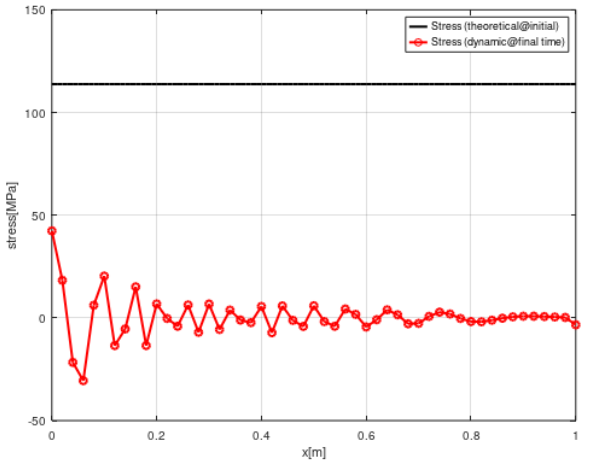

b)

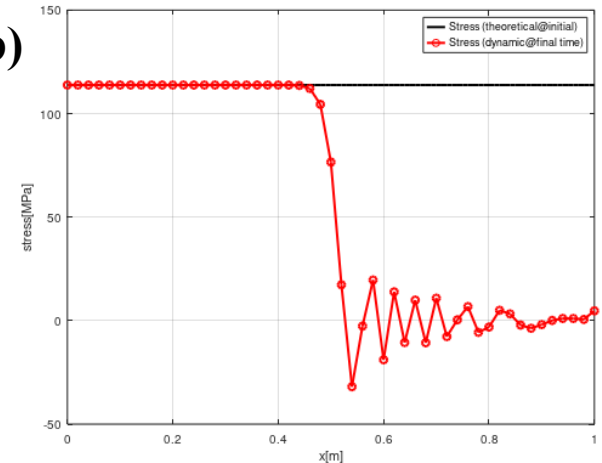

d)

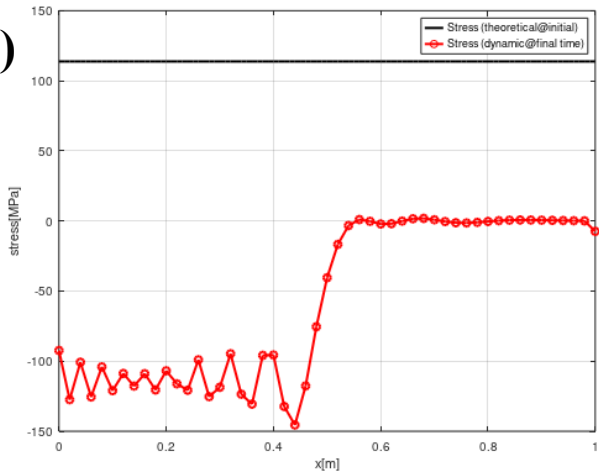

Fig. 8 Dynamic stress distribution in Ti6Al4V (Grade5) rod for various values time $u_{0}=1 \mathrm{~mm}$, (a) $t=0 s$, (b) $t=t_{r} / 2$, (c) $t=t_{r}$, (d) $t=3 / 2 t_{r}$. 
a)

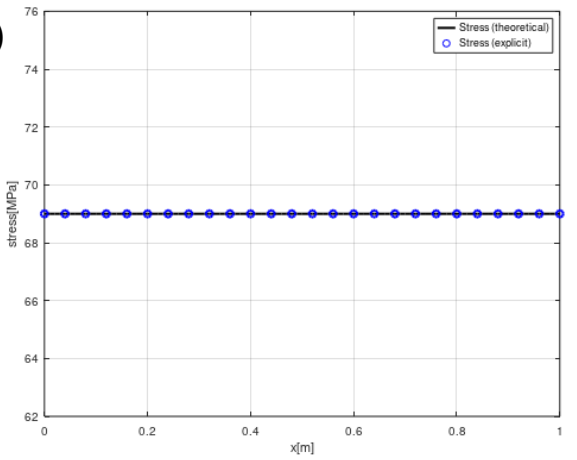

c)

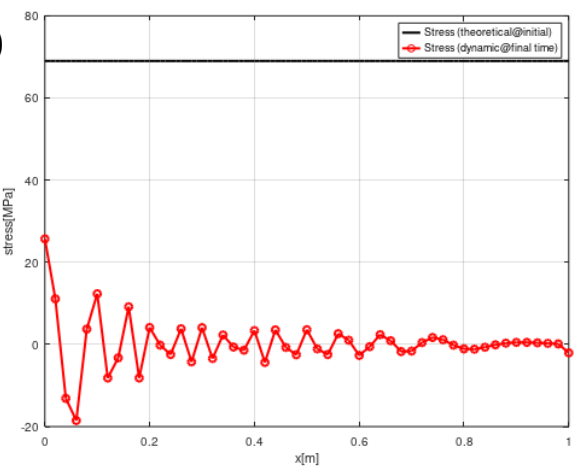

b)

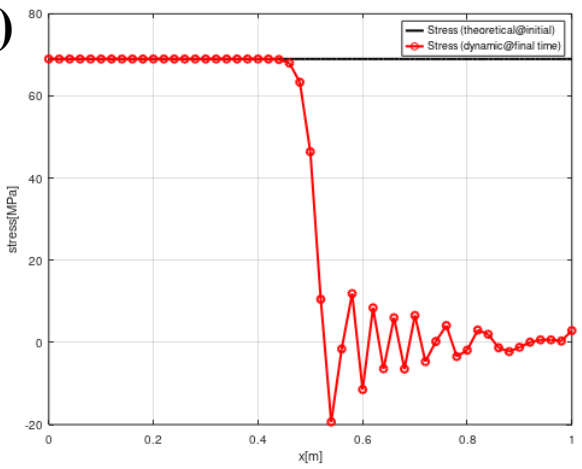

d)

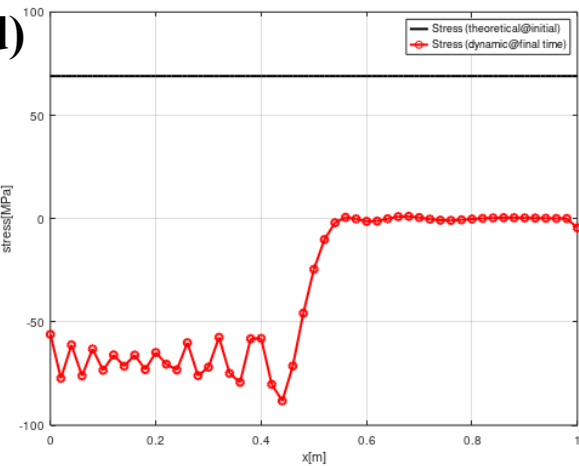

Fig. 9 Dynamic stress distribution in Al6061 Alloy rod for various values time $u_{0}=1 \mathrm{~mm}$, (a) $t=0 \mathrm{~s}$, (b) $t=t_{r} / 2$, (c) $t=t_{r}$, (d) $t=3 / 2 t_{r}$.

\section{Discussions}

Structural steel AISI 1006 (CD), AISI 1020 (CD), Ti6Al4V and Aluminium alloys such as $\mathrm{Al} 6061$ are widely used in many engineering fields such as mechanical, automotive, aerospace and energy. Therefore, dynamic response of these materials has a considerable importance in mechanical assemblages. Problem is handled considering elastic rod with uniform cross-section made of different materials. Longitudinal wave propagation is modelled using one-dimensional (1D) wave propagation equation. Boundary and initial conditions are determined. In order to find dynamic displacement and stress distribution, wave equation is solved by means of analytical and computational methods. Computational method is developed based on discretization of the PDE with explicit scheme. Analytically and computationally developed results exhibit a very good agreement, which shows accuracy and reliability of the computational method. Then, parametric analyses are carried out to assess the effects of time, level of tip load and material type on dynamic displacement and stress behaviour.

- Wave propagation speed is the minimum for the AISI 1020 (CD) steel while it is maximum for AISI 1006 (CD) steel. Natural frequencies are:

$$
\omega_{A I S 11020(C D)}<\omega_{A l 6061}<\omega_{T i 6 A l 4 V}<\omega_{A I S H 1006(C D)}
$$

- Increase in the initial tip displacement leads to increase in the dynamic stress distribution.

- Before the reflection of the wave at $t=t_{r} / 2$, dynamic stress is positive within $[0, L / 2]$, and it is zero in $[L / 2, L]$.

- At the reflection time $t=t_{r}$, stress is zero throughout the rod. Very small rises and drops occur due to the rounding errors of the computational method. However, it can be acceptable.

- After the reflection of the wave at $t=3 t_{r} / 2$, dynamic stress is negative within $[0, L / 2]$, and it is zero in $[L / 2, L]$.

- The level of dynamic stress is obtained as:

$$
\sigma_{A l 6061}<\sigma_{T i 6 A l 4 V}<\sigma_{A I S 11020(C D)}<\sigma_{A I S 1006(C D)}
$$

\section{Conclusions}

The following main conclusions can be drawn from this study:

- Developed computational method based on explicit scheme is observed fast and reliable in determination of dynamic displacement and stresses distribution within elastic rod made of various materials.

- Analytical solution for wave propagation problems may not easily be found for machine parts with non-uniform cross-section and non-homogenous boundary conditions. Developed computational technique can be used to find dynamic response of machine components made of different materials under various boundary and initial conditions.

\section{References}

Inagaki, I., Takechi, T., Shirai, Y., Ariyasu, N. (2014). Application and features of titanium for the aerospace industry. Nippon Steel \& Sumitomo Metal Technical Report, 22-27. 
Boyer, R.R. (1996). An overview on the use of titanium in the aerospace industry. Materials Science and Engineering: A, 213(1), 103-114.

Singh, P., Pungotra, H., Kalsi, N.S. (2017). On the characteristics of titanium alloys for the aircraft applications. Materials Today Proceedings, 4(8), 8971-8982.

Uhlmann, E., Kersting, R., Klein, T.B., Cruz, M.F., Borille, A.V. (2015). Additive manufacturing of titanium alloy for aircraft components. Proc. CIRP, 35, 55-60.

Jeon, G.T., Kim, K.Y., Moon, J-H., Lee, C., Kim, W-J., Kim, S.J. (2018). Effect of Al6061 Alloy Compositions on Mechanical Properties of the Automotive Steering Knuckle Made by Novel Casting Process. Metals, 8, Article 857.

Sharma, M.M., Ziemian, C.W., Eden, T.J. (2011). Fatigue behaviour of $\mathrm{SiC}$ particulate reinforced spray-formed 7xxx series al-alloys. Materials \& Design, 32, 4304-4309.

Vijayarangan, S., Rajamanickam, N., Sivanant, V. (2013). Evaluation of metal matrix composite to replace spheroidal graphite iron for a critical component, steering knuckle. Materials \& Design, 43, 532-541.

Prescott, M.A. (1942). Elastic Waves and Vibrations of Thin Rods. The London, Edinburgh, and Dublin Philosophical Magazine and Journal of Science, 33(225), 703-754.

Kolsky, H. (1954). The propagation of longitudinal elastic waves along cylindrical bars. The London, Edinburgh, and Dublin Philosophical Magazine and Journal of Science, 45(366), 712-726.

Hutchinson, J.R. (1972). Axisymmetric vibrations of a free finite length rod. Journal of the Acoustical Society of America, 51, 233-240.

Hutchinson, J.R. (1980). Vibrations of solid cylinders. Journal of Applied Mechanics. 47, 901-907.

$\mathrm{Xu}, \mathrm{D}$., Du, J., Liu, Z. (2019). An accurate and efficient series solution for the longitudinal vibration of elastically restrained rods with arbitrarily variable cross sections. Journal of Low Frequency Noise, Vibration and Active Control, 38(2), 403-414.

Yang, H., Li, Y., Zhou, F. (2021). Propagation of stress pulses in a Rayleigh-Love elastic rod. International Journal of Impact Engineering, 153, Article 103854.

Cangellaris, A.C. (1993). Numerical Stability and Numerical Dispersion of a Compact 2-D/FDTD Method Used for the Dispersion Analysis of WaveGuides. IEEE Microwave and Guided Letters, 3(1), 3-5.

Matweb. (2021). www.matweb.com. Matweb material property data. Online Accessed: 05/10/2021. 